УДК 336.7.12.3

\title{
УПРАВЛІННЯ ФІНАНСОВИМ ПОТЕНЦІАЛОМ ПІДПРИЕМСТВА НА ОСНОВІ КОНКУРЕНТНОЇ РОЗВІДКИ
}

\author{
Науменко М.О., д. філос. (екон.), професор, \\ Бережний Д.О., студент-магістр (НАНГУ)
}

У даній статті представлено технологію управління фінансовим потенціалом підприємства на основі конкурентної розвідки. В роботі виділені наступні особливості конкурентної розвідки в прочесі управління фінансовим потенціалом підприємства. Пропонується послідовність дій, які керівництвву підприємства слід виконати для досягнення успіху бізнес-розвідки в умовах управління фінансовим потенціалом. На підставі аналізу проблем конкурентної розвідки та дослідження літературних джерел в статті запропоновано основні рекомендації керівництву підприємства щуодо організаціі системи моніторингу конкурентного середовища в процесі управління фінансовим потенціалом підприємства.

Ключові слова: фінансовий потенціал, конкурентна розвідка, управління, підприємство, конкурентне середовище, моніторинг

\section{УПРАВЛЕНИЕ ФИНАНСОВЫМ ПОТЕНЦИАЛОМ ПРЕДПРИЯТИЯ НА ОСНОВЕ КОНКУРЕНТНОЙ РАЗВЕДКИ}

\author{
Науменко М.А., д. фил. (эконом.), профессор, \\ Бережной Д.О., студент-магистр (НАНГУ)
}

В данной статье представлено технологию управления финансовым потенциалом предприятия на основе конкурентной разведки. В работе выделены следующие особенности конкурентной разведки в прочессе управления финансовым потенциалом предприятия. Предлагается последовательность действий, которые руководству предприятия следует выполнить для достижения успеха бизнес-разведки в условиях управления финансовым потенциалом. На основании анализа проблем конкурентной разведки и исследования литературных источников в статье предложены основные рекомендаџии руководству предприятия по организации системы мониторинга конкурентной среды в прочессе управления финансовым потенциалом предприятия.

Ключевые слова: финансовый потенциал, конкурентная разведка, управление, предприятие, конкурентная среда, мониторинг

\section{MANAGEMENT OF FINANCIAL POTENTIAL OF THE ENTERPRISE BASED ON COMPETITIVE EXPLORATION}

\author{
Naumenko M., PhD (Econ.), Professor, \\ Berezhnyi D., Master's Degree (NANGU)
}

This article presents the technology of managing the financial potential of an enterprise on the basis of competitive intelligence. The purpose of competitive intelligence and the main categories of tasks that are solved in the course of managing the financial potential of the

(C) Науменко M.O., Бережний Д.О.

Вісник економіки транспорту і промисловості № 67, 2019 
company through competitive intelligence. The following features of competitive intelligence in the process of managing the financial potential of the enterprise are highlighted in the paper. The basic questions that competitive intelligence analysts should ask when receiving a request in the process of managing the financial potential of an enterprise are analyzed. Weaknesses of information that is usually provided through competitive intelligence are identified and analyzed. The sequence of actions that the management of the company should take to achieve the success of business intelligence in terms of financial potential management is proposed. The main components of the organizational structure of competitive intelligence are highlighted. On the basis of the analysis of the problems of competitive intelligence and research of literary sources, the article offers the basic recommendations to the management of the enterprise on the organization of the system of monitoring the competitive environment in the process of managing the financial potential of the enterprise. Emphasis is placed on the need for competitive intelligence to be pursued in specific functional areas (eg, production, marketing), thus creating decentralized networks of competitive intelligence teams coordinated by senior management of the enterprise. The basic tasks which the management of the enterprise should be singled out in the structure of a complex of tasks of competitive intelligence for the purpose of their earliest warning and due to the high level of their importance for the strategy of the enterprise are specified. The further direction of this research may be to develop a methodology for managing the financial potential of an enterprise in an information economy.

Keywords: financial potential, competitive intelligence, management, enterprise, competitive environment, monitoring

Постановка проблеми. 3 метою ефективного управління фінансовим потенціалом підприємства актуального значення набуває залучення експертів і аналітиків до дослідження релевантної інформації зовнішнього середовища компанії. Фінансовому аналітику інформація про зовнішне середовище здебільшого подається у вигляді відповідних інформаційних ресурсів (IP). Процес збору, аналізу та використання інформації про ресурси, вразливі точки конкурентів i їх наміри, проведення моніторингу конкурентного середовища отримав назву конкурентної розвідки (КР). Основна мета КР - зібрати відомості, які можуть забезпечити корпорації вирішальні конкурентні переваги в процесі управління фінансовим потенціалом підприємства.

Основними категоріями завдань, що вирішуються в ході управління фінансовим потенціалом підприємства за допомогою KP, €:

- розробка стратегічних і тактичних рішень і дій;

- аналіз проблеми та забезпечення раннього ії попередження;
- витяг знань про основні суб'єктах даного сектора ринку і вивчення їх досвіду.

Аналіз останніх досліджень i публікацій. У роботах [2-6] аналізуються особливості ведення конкурентної розвідки в компаніях, розглядаються методи конкурентної розвідки. Питання проектування інтелектуального користувацького інтерфейсу систем електронного навчання з метою здійснення конкурентної розвідки підіймається в досліджені [7]. Веб-базовані інструменти ведення конкурентної розвідки систематизовані у науковій статті [8]. Напрямки вдосконалення управління трудовими ресурсами підприємства завдяки використанню конкурентної розвідки наведені в роботі [9].

Виділення невирішених частин загальної проблеми. Однак в публікаціях не представлений цілісний підхід до моніторингу конкурентної розвідки для управління фінансовим потенціалом організації. Внаслідок цього актуального значення набуває дослідження в науковій площині даного виду моніторингу зовнішнього середовища. 
Метою даної статті $\epsilon$ розроблення технології управління фінансовим потенціалом підприємства на основі конкурентної розвідки.

Викладення основного матеріалу дослідження. На основі літературних джерел [2-5] були виділені наступні особливості конкурентної розвідки в процесі управління фінансовим потенціалом підприємства:

1. Програми КР зазвичай виконуються відділами маркетингу, планування, досліджень i розробок. Більшість фахівців КР проводять менше 50 відсотків свого робочого часу, вирішуючи завдання, безпосередньо пов'язані 3 розвідувальною інформацією.

2. Роль КР-програм в організації визначається потребами підприємства, які часто пов'язані 3 недостатньою віддачею активів. Програми КР запускаються часто не в профілактичних цілях, а вже при безпосередньому виникненні проблеми в бізнесі.

3. Конкретне розуміння ролі КР дуже важливо; навіть якщо ця роль обмежена і вузько сфокусована, необхідно вибудувати адміністративну структуру для iii виконання. Основні процеси реалізації КР, такі, як подача та виконання запитів, $\mathrm{i}$ аналітичні бази даних повинні бути задокументовані.

В процесі управління фінансовим потенціалом підприємства під час отримання запиту аналітики КР повинні задати два ключових питання:

1. Перед початком виконання проекту: «Як ви збираєтеся використовувати цю інформацію або рішення якого типу ви хочете прийняти?»

2. Після завершення проекту: «Що ще вам потрібно дізнатися?»

Успіх бізнес-розвідки в умовах управління фінансовим потенціалом підприємства досягається при дотриманні наступної послідовності дій:

1. Передача споживчому сегменту чіткого уявлення про можливості, перспективи та плани КР;
2. Пошук споживачів інформації i встановлення з ними контактів;

3. Складання чіткого списку пріоритетних завдань i критеріїв оцінки успішності їх досягнення;

4. Забезпечення виконання стратегічних програм, що задовольняють запити, пріоритетні для майбутнього корпорації.

Користувачі КР зазвичай відзначають наступні недоліки наданої інформації [5]:

- інформація занадто поверхнева i, в основному, являє собою матеріали із засобів масової інформації, яка підготовлена журналістами та фахівцями 3 PR (взаєминам з громадськістю);

- проблема достовірності;

- несвоєчасність;

- основний фокус. В контексті цього користувачі бажають отримати готовий звіт, на утримання якого і на методи збору інформації та для якого вони хотіли б вплинути;

- адресати, яким надсилається інформація. Користувачі хочуть знати, яким чином вони можуть брати участь в зборі розвідувальної інформації.

На підставі вищевикладених проблем конкурентної розвідки та аналізу літературних джерел $[4,6,8,9]$ можна запропонувати наступні рекомендації керівництву підприємства щодо організації системи моніторингу конкурентного середовища в процесі управління фінансовим потенціалом підприємства:

1) внаслідок своєї стратегічної ролі конкурентна розвідка повинна плануватися i бути регульованою в системі менеджменту, яка має дбати про раннє попередження конкурентних чинників;

2) організаційна структура КР повинна передбачати наявність таких компонентів:

a) підсистема дослідження відповідає за збір інформації та фільтрацію великих обсягів даних, що надходять. Підгрупа, яка відповідає за функціонування даної підсистеми, повинна підключатися до 
роботи по конкретних завдань і проектів. Учасникам підгрупи повинні бути поставлені конкретні цілі зі збору інформації, i їх завданням буде забезпечувати безперебійні інформаційні потоки для корпоративної розвідки;

б) бібліотека розвідувальної інформації - відповідає за створення i функціонування корпоративного сховища розвідувальної інформації. У такій базі даних будуть як паперові, так і цифрові носії. Бібліотека стане також відповідати за пошук нових технологій управління інформацією, які можуть бути корисні для збору і поширення інформації всередині підприємства;

в) підсистема стратегічної маркетингової розвідки - має займатися такими видами діяльності, як фільтрація, узагальнення та інтерпретація інформації, підготовленої дослідницьким відділом;

3) забезпечення обізнаності співробітників всіх рівнів ієрархії в програмі КР i наявності ефективних каналів комунікації всередині підприємства;

4) слід організувати систематичне i регулярне ведення конкурентної розвідки і забезпечити іiі включення в організаційну структуру підприємства. У стратегічному плануванні діяльності організації необхідно передбачити реалізацію циклу базових операцій КР;

5) ведення конкурентної розвідки слід здійснювати по окремих функціональних напрямах (наприклад, виробничому, маркетинговому), створюючи, таким чином, децентралізовані мережі груп КР, координовані вищим рівнем керівництва підприємства;

6) в структурі комплексу завдань КР необхідно окремо виділити групу завдань, що вимагають найбільш раннього попередження внаслідок високого рівня їх значимості для стратегії підприємства. Такими завданнями слід вважати виявлення таких чинників:

a) області можливих технологічних «проривів»; б) технологічні розробки та їх використання конкурентами та іншими підприємствами;

в) стан і показники роботи основних постачальників;

г) зміни стратегічно важливих параметрів в галузі;

д) зміна в сприйнятті послуг підприємства 3 боку клієнтів / конкурентів;

е) підприємства, які розглядають можливість проникнення в нашу сферу бізнесу або на наші ринки;

ж) зміни в міжнародній політичній, соціальній, економічній чи правовій / нормативній ситуації, які можуть вплинути на конкурентоспроможність підприємств;

3) питання нормативного регулювання: зміни в короткостроковому плані; відхилення в довгострокові тенденції; інші урядові зміни, які можуть вплинути на існуючі регулюючи порядки;

i) розвідувальна інформація про альянси, придбання i продаж активів конкурентами, клієнтами та постачальниками;

к) фінансові ініціативи основних конкурентів.

В цілому, в процесі управління фінансовим потенціалом наявність системи конкурентної розвідки дозволить підприємству вийти на передові позиції інформаційного ринку, наперед прогнозуючи можливі сценарії його розвитку [10].

Висновок. Таким чином, у даному дослідженні запропоновано технологію управління фінансовим потенціалом підприємства на основі конкурентної розвідки.

Науковою новизною даної роботи $є$ запропонована методика управління фінансовим потенціалом на основі конкурентної розвідки.

Подальшим напрямком даного дослідження може стати методика оптимізації фінансової програми розвитку підприємства. 


\section{ПЕРЕЛІК ВИКОРИСТАНИХ ДЖЕРЕЛ} аспекти

1. Каличева Н. Є. Методологічні конкурентоспроможності підприємств залізничного транспорту за рахунок управління конкурентними позиціями. Науковий вісник Херсонського державного університету. Сер.: Економічні науки. Херсон, 2017. Вип. 27. Ч. 1. -С. 139 - 142.

2. Hrabovskyi Y. Methods of Assessment and Diagnosis of the Quality of Knowledge in E-Learning. Journal of Communication and Computer. 2015. № 12. - P. 286-296.

3. Черкашина М. В. Розробка методики управління підготовкою персоналу для систем просування товарів в умовах постіндустріального суспільства. ScienceRise. 2019. -№ 2-3. -C. 28-31.

4. Соколовський С. А., Науменко М. О. Аналіз особливостей управління інформаційними потоками логістичних процесів підрозділів Національної гвардії України. ScienceRise. 2018. № 2. С. 19-21.

5. Hu C., Yang Z, Mingjing G. AHP and CA Based Evaluation of Website Information Service Quality: An Empirical Study on High-Tech Industry Information Center Web Portals//Journal Service Science \& Management. 2009. № 3. P. 168-180 DOI: https://doi.org/10.4236/jssm.2009.23020

6. Пушкарь А.И., Грабовский Е.Н., Пономаренко Е.В. Стратегическое управление развитием электронного бизнеса и информационных ресурсов предприятия. Х.: Изд-во ХНЭУ, 2005. $480 \mathrm{c}$.

7. Грабовський $€$. М. Проектування інтелектуального користувацького інтерфейсу систем підтримки електронного навчання. Scientific Journal «ScienceRise». № 11(52). 2018. -C. 36-39

8. Martins P., Zacarias M. A Webbased Tool for Business Process Improvement//International Journal of Web Portals. 2017. Volume 9. Issue 1. P. $68-84$ DOI: 2017070104
9. Соколовський С. А., Науменко М. O., Черкашина М. В. Удосконалення управління трудовими ресурсами підприємства. Бізнес Інформ. 2015.№ 3. C. 288-292.

10. Каличева Н. Є. Вплив інформаційних технологій на ефективність функціонування вітчизняної транспортнологістичної системи в сучасних умовах. Актуальні проблеми та напрями розвитку потенціалу соціально-економічних систем в умовах конкурениії: монографія/ за заг. редакцією д-ра екон. наук, професора Л. Л. Калініченко. Харків: ФОП Панов А.М. Видав. ТОВ «В справі», 2017. С. 201-210.

\section{REFERENCES}

$$
\text { 1. Kalicheva N.E. }
$$

Metodologhichni aspekty pidvyshhennja konkurentospromozhnosti pidpryjemstv zaliznychnogho transportu za rakhunok upravlinnja konkurentnymy pozycijamy [Methodological aspects of increasing the competitiveness of railway companies through the management of competitive positions]. Scientific Herald of Kherson State University. Series: Economic Sciences. Vol. 27. No 1, pp. $139-142$

2. Hrabovskyi Y. (2015). Methods of Assessment and Diagnosis of Knowledge Quality in E-Learning. Journal of Communication and Computer. No. 12, pp. 286-296.

3. Cherkashina M. V. (2019) Rozrobka metody`ky' upravlinnya pidgotovkoyu personalu dlya sy`stem prosuvannya tovariv $\mathrm{v}$ umovax postindustrial`nogo suspil`stva. [Development of methods of management training of personnel for systems of promotion of goods in conditions of post-industrial society]. ScienceRise. Vol. 2-3, pp. 28-31.

4. Sokolovskyi S. A., Naumenko N. A. (2018). Analiz osobly`vostej upravlinnya informacijny`my` potokamy` logisty`chny`x procesiv pidrozdiliv Nacional noyi gvardiyi Ukrayiny. [Analysis of peculiarities of management of information flows of logistic 
processes of units of the National Guard of Ukraine]. ScienceRise. No 2, pp. 19-21.

5. Hu C., Yang Z, Mingjing G. AHP and CA Based Evaluation of Website Information Service Quality: An Empirical Study on High-Tech Industry Information Center Web Portals//Journal Service Science \& Management. 2009. № 3. P. 168-180 DOI: https://doi.org/10.4236/jssm.2009.23020

6. Pushkar A.I., Grabovsky E.N., Ponomarenko E.V. (2005). Strategy`cheskoe upravleny`e razvy`ty`em Эlektronnogo by`znesa y` y`nformacy`onnix resursov predpry`yaty ya [Strategic Management of the Development of E-Business and Information Resources of Enterprise]/ Kharkiv: KhNPU Publishing House, 480 p. (in Ukrainian).

7. Grabovsky E. M. (2018). Proektuvannya kory`stuvacz`kogo interfejsu sy`stem pidtry`mky` elektronnogo navchannya [Designing the Intelligent User Interface of ELearning Support Systems]. Scientific Journal «ScienceRise». No. 11 (52), pp. 36-39

8. Martins P., Zacarias M. A (2017). Web-based Tool for Business Process
Improvement // International Journal of Web Portals. Vol 9. Issue 1,pp. 68 - 84 DOI: https://doi.org/10.4018/IJWP.2017070104

9. Sokolovsky S. A., Naumenko M. O., Cherkashina M. V. (2015) . Udoskonalennya upravlinnya trudovy'my resursamy` pidpry`yemstva. [Improvement of the management of labor resources of the enterprise]. Business Inform. № № 3, pp. 288292.

10. Kalicheva N. E. (2017). Vply`v informacijny`x texnologij na efekty 'vnist` funkcionuvannya vitchy`znyanoyi transportno-logisty`chnoyi sy`stemy` v suchasny`x umovax. [Influence of information technologies on efficiency of functioning of domestic transport-logistic system in modern conditions]. Aktual'ni problemy ta napryamy` rozvy`tku potencialu social'noekonomichny` $x$ sy`stem $v$ umovax konkurenciyi: monografiya. [Actual problems and directions of development of potential of socio-economic systems in the conditions of competition: monograph]. Kharkiv: FOP Panov AM Issued. LLC In Business, pp. 201210. . (in Ukrainian)

\title{
УДК 004.15.7
}

\section{ПІДВИЩЕННЯ ЕФЕКТИВНОСТІ МАРКЕТИНГОВИХ ЗАХОДІВ ПІДПРИСМСТВА НА ОСНОВІ ЗАБЕЗПЕЧЕННЯ НАДІЙНОСТІ ПРОГРАМНОГО ЗАБЕЗПЕЧЕННЯ}

\author{
Науменко М.О., д. філос. (екон.), професор, \\ Щербина Н.С., студент-магістр (НАНГУ)
}

\begin{abstract}
У даній статті подано технологію підвищення ефективності маркетингових заходів підприємства на основі забезпечення надійності програмного забезпечення. У дослідженні вказано, щчо питання забезпечення якості та надійності програмного забезпечення вважається більш важливим, ніж питання його оиінки. У статті окремо проаналізовано основні особливості управління апаратною компонентою програмного забезпечення систем маркетингу. Акцентується увага на необхідності розрізняти надійність загально-структурних апаратних засобів $i$ надійність апаратних засобів користувача, які застосовуються для роботи з мультимедійними ресурсами систем маркетингу.
\end{abstract}

